\title{
COITUS IN THE SYMBOLIC LANGUAGE OF SLAVIC CULTURE
}

\section{Aleksandr V. Gura}

\begin{abstract}
Folk culture considers sexual intercourse unclean and dangerous and therefore applies many restrictions to it. Usually coitus is referred to with euphemisms and other substitutes that can be both neutral and expressive, or even humorous. Symbols of coitus in popular culture are numerous and diverse. Coitus is one of the most important objects of allegory among different types of human activity. In traditional popular culture it corresponds to a wide paradigm of behavioural symbols. The paradigm is built on the basis of motivating indicators reflecting the external properties of action: joining together, mobility, insertion, rhythm and repetitive action, oscillation, friction at close contact, etc. The basis of the symbolic meanings attributed to sexual intercourse as a means of magic of traditional popular culture is the similarity of physical sexual contact to social contacts (marriage, ritual relations), as well as metaphorical extrapolation of its natural result (conception of the fetus) to the results of human activity (harvest, cattle, big game hunting or fishing).
\end{abstract}

Keywords: coitus, erotic folklore, erotic symbolism, euphemism, folklore, Slavic culture, symbolic meaning, customs

Folk culture considers sexual intercourse as unclean and dangerous and therefore applies many restrictions to it. The reason for tabooing coitus is the perception thereof as an unclean, and in the Christian understanding also a sinful and therefore shameful affair. Russians and other Orthodox Slavs have a custom to cover icons or turn their faces to the wall and remove the pectoral cross during coitus, as well as pray before and after coitus (see: Uskpenski 1982: 184; Haase 1939: 250; Stern 1908: 505). In the Russian North, the bride and groom did not receive communion and did not confess their sins for a year after the first matrimonial night, considering this a sin (Zavarin 1870: 101). The Slavs thought that an imprint of "impurity" quite often remained on the young wife until giving birth to a child (Stern 1908: 507). And Bulgarians thought that sexual intercourse of unmarried couples or infidelity to a spouse may cause draught or hail. ${ }^{1}$ 
Despite this attitude to coitus some circumstances allowed freedom of sexual behaviour, especially among young people, who in general enjoyed special behavioural norms (for example, Russian girls in the North often did not go to church before marriage and this was not blameworthy). In different Russian regions at evening parties guys and girls played with the lights off and often the party resulted in an orgy (Bernstam 1988: 243). Community celebrations like 'bratchina' allowed for sexual intercourse among adults, including coition of close relatives, e.g. daughter-in-law with brother-inlaw or father-in-law, even coitus of married brothers with married sisters was not considered sinful (Bernstam 1988: 227-228). Only signs of old age imposed restrictions on coitus for Eastern Slavs loss of capacity to work, moral prohibition to give birth after fifty years of age as well as marriage of all children. In the Ukraine people said about old couples who no longer slept together: "They have washed their hands" (Bernstam 1988: 68). Therefore the older married couples who no longer had marital intercourse were considered "pure."

Usually coitus is referred to with euphemisms and other substitutes that can be both neutral and expressive, or even humorous. Examples: Rus. грех, согрешить, пакостить, валять, отделать, отработать, жениться, Ukr. боже сохрани, мусолить, лизать (compare потайний язик 'penis'), Pol. kochać się, pieprzyć się, dupczyć, Bulg. онодям, она работа, въриа тази работа, Serbian прчити, поклопити, навршити, сиграти се. Many coitus designations are based on similarities to different movements: yanking (Ukr. шморгаться from шиоргати 'yank'), beating (Ukr. чухраться - from чухрати 'beat, thump', Serbian кундачити - literally 'beat with a rifle butt'), pounding (Rus. толочь), waving (Rus., Ukr. махать, махаться, вымахать), rolling (Rus. вертеть), somersaulting (Rus. кувыркаться), dancing (Ukr. таниювать у читирі коліна кадрель), horse riding (Serbian jахати), moving in general (Serbian мрдати - literally 'move, budge, revolve,' Pol. ruchać, wyruchać - from ruch 'motion') (see: SRNG, ed. 9: 126; Balashov \& Marchenko \& Kalmykova 1985: 296; Afanasev 1992: 32, 59, 70, 73; Krauss 1909: 18, 21, 22, 26, 32, 140, 270, 273, 366, 434; Badalanova 1993: 159, 189, 225, 229; Kryptadia 1899: 197). There are special euphemisms to describe the marital intercourse of newlyweds on their first night: Rus. (Vologda) знаться, Bel. (Vitebsk), спознациа (Zelenin 1914a: 134-140). 
Traditional popular beliefs also underlie the Ukrainian names of extramarital sexual relations: скочити в горох and побратися в заячому холодку (Komarov 1890: 83). The first expression is linked to the erotic symbolism of the pea and its role in stimulating child birth. Czechs threw peas at the bride at a wedding and guessed the number of future children by the number of peas stuck in her dress; the pea was the main course at a Polish wedding and a pea straw wreath as the symbol of lost innocence. Russian покушать горошку, гороху объесться (lit. 'to eat pea'), Pol.grochu się objadła, Kashubian vlezc $v$ grochovinë mean pregnancy, usually extramarital (Plotnikova \& Usacheva 1995: 524-525). The second expression has a link to the erotic and phallic symbolic meaning of the hare, which is often a successful lover in folklore texts, making love to girl, dishonouring a she-fox or a she-wolf, etc. (see Gura 1997: 180-184).

Symbols of coitus in popular culture are numerous and diverse. The most transparent of them are actions of penetration and insertion. For example, driving something into something describes coitus in common language and in erotic folklore texts. Ukr. потикаться, Bulg. забуча с един stake, забоди ги аt касата (Krauss 1909: 26; Baladanova 1993: 183). Battering - Serbian дубити 'futuere' (Krauss 1904: 445). Going though a hole - a Byelorussian round dance song about a hare (see above the phallic symbolism of this animal):

Праскачы, зайка, у дзірачку, Jump, hare, through a hole Да выламі сабе да быліначку And break a stick

(Dzitsiachy 1972: 444)

To blow - the Russian word for coitus вдуть, and also a song from Kaluga speak about the nightingale's sexual intercourse with a cuckoo bird:

Как на ветке, на макушке

Соловей задул кукушке.

А кукушке хорошо, Поджимает хвост еше.
On the branch, on the tree top A nightingale screwed a cuckoo bird. A the cuckoo bird likes it, She raises her tail again. ${ }^{2}$

The popular belief establishes a close relation between the nightingale and cuckoo, and in folklore texts they often represent a married couple and bear's sexual symbolical meaning. Compare Bulgarian dialect names for female genitals: кукувица, кукуля (Bada- 
lanova 1993: 157, 170,171, 195). Making holes is the sexual connotation of the verb решетить (literally 'make a sieve of something, sieve something') in one of the Russian "forbidden tales" - erotic stories collected by A. N. Afanasiev. A soldier at a wedding gets a sieve and he is offered to "порешетить" the newly married couple, i.e. give them some money. Решетить так решетить, говорит, да идет без портков, как спал, берется за решето, и прямо поднял простыню и давай молодую решетить через жопу 'OK, let it be a sieve, he says, and goes without trousers, as he was sleeping, takes the sieve and just raises the sheet, and begins sieving the bride to the ass' (Afanasev 1992: 114).

A sting, or bite, is an especially popular symbol of coitus. For example, Kashubs say about pregnant women: $p$ ščła ugrëzła 'bee sting' (Sychta 1967-1976: 5: 34). Byelorussians interpret a young woman's dream of a bee stinging as a sign of imminent pregnancy. Молодой баби, коли жало упустя - забеременея 'If (a bee) inserts its stinger in a young woman, she will become pregnant' (Romanov 1889: 70). The indirect connection of a bee stinging with coitus is also reflected in a Northern Russian legend about Adam and Eve: Член у Адама от холода набух. Вот и решил он его упрятать, где потеплее. И прижался им к $E_{6 е}$ сзади. А тут пчела Адама в зад укусила. Тот дернулся вперед, и пошла у них потеха. 'Adam's penis swelled with cold. He decided to hide it in a warm place. And pressed it into Eve from behind. Suddenly a bee stung Adam's rear. He twitched forward and the fun began' (Loginov 1996: 452).

In Ukrainian and Byelorussian wedding songs, describing the first marital night, the hornet's sting symbolises the defloration of the bride:

Прилетів шершень з стели та ўпав на постелі;

де Марусенька спала, там рожа процвитала, а від теперь де буде спати, там буде упадати!

(Kolberg 1962c: 335)

Прылецел, мамко, шэрсень, Да й утылкуу у жало,
A hornet came from the ceiling And fell on the bed Where Marusenka was sleeping, And a rose flourished Now he will always fall Where she is sleeping!

'A hornet, mama, came And stuck his stinger, 
Да й утыкнуу жало,

Сэриэ мае задрыжало.

Деўку не за пуп, да за чэрэво

Укусіў па середу

(Byelorussia, Gomelskaya Oblast, recorded by the author)

And stuck his stinger,

My heart trembled.

But in the very womb
He stung a girl not in the navel

Here we should add that the penis can be somehow euphemistically described as a stinger: Ukr. Жильие (Krauss 1908: 211, 218).

In Polish comic songs a fly bites a foreigner in the rear or flies into the rear:
Posed Mimiec na Kaminiec
Kapusty kupować;
A German went to Kamenets
Uzarła go mucha $w$ d..o, To buy cabbage,
Musiał pokutować
A fly bit him in the rear,
He had to confess (i.e. regret his sinful intention)

(Gonet 1909: 130)

Posed Moskal na jarmarek, A Russian went to fair

Kapuste kupować; $\quad$ To buy cabbage;

Wleciała mu mucha w tyłek, A fly flew to his rear,

Musiał jom ćwiertować He had to quarter it

(Rawicz-Witanowski 1893: 82)

We can understand the comic effect only if we reveal the hidden symbolic meaning of the text: a foreigner is going to have sexual intercourse with a woman (goes to buy cabbage, a common female sexual symbol in folklore) and exactly at this moment he himself becomes the object of sexual violence (a fly bites or flies into his rear).

The theme of the hare bite, widely used in Polish folklore songs, reflects the same erotic symbols. For example, see a wedding song:

Kole lasa, kole lasa

goniła zająca,

ukąsił ją $w$ palec mały

jaze do boląca
Near the forest, near the forest

She was running after a hare,

He painfully bit

Her little finger

then follows a theme of losing a wreath (symbol of lost virginity) and marriage (Kolberg 1962a: 66). Another song warns the girl: 
Dziwcyno nasa, nie chodź do lasa,

Our girl, do not go to the forest,

W lesie zajunce pokusajo cie In the forest the hares will bite you (Skierkowski 1929: 127)

Hare hunting is also a symbol of coitus, popular in Polish songs (See, for example, Skierkowski 1933: 80, 236, 334). A Moravian joke marně vyháněl $z$ díry zajice 'in vain he forced the hare out of its hole' is also a metaphor of coitus (Jakobson 1934-1936: 78). A dream of a hare is a forecast of sexual intercourse according to Russian and Ukrainian dream interpretation books of the XVII century: хто более заииы восне видит болше воблуде будеть жити 'he who often sees a hare in his dreams will often have sexual affairs'3; заица есть cb бабою пребыть знаменует 'to eat a hare - betokens sexual intercourse with a woman'; заячое мясо исты, грІхъ зъ женою знаменуе 'to eat hare meat betokens "sin" (sexual intercourse with a woman)'. ${ }^{5}$

A wolf biting or gnawing its game also often bears the erotic meaning of coitus. For example, the following Serbian tale from Herzegovina shows the symbolic relation of wolf bites with coitus and a wolf tooth with a penis. A stupid woman was afraid of a wolf; once, when she was in the field, it began raining - the woman hid headlong in a haycock and fell asleep. A shepherd, who happened to pass by, noticed her bare end protruding from hay and committed a sexual act. The happy woman thought that a wolf was biting her and praised his soft teeth (Krauss 1904: 445). Another example of symbolic coitus is a Polish comic song about wolves who sat on the woman's rear and ate her:
Wilcy babe jedzom;
Wolves are eating a woman, Juz ji teb ujedli, A na tylku siedzom
Already have consumed her head, Sitting on her rear

(Rawicz-Witanowski 1983: 75)

This symbol of a wolf's bite explains the use of some types of coitusrelated amulets, protecting from wolves. Thus, young Bulgarian women who slept with their husbands were forbidden to touch animal fat and curd on the so-called "wolf days" (the days related to wolf-protection amulets) in order to protect cattle from wolves. ${ }^{6} \mathrm{~A}$ Ukrainian husband had to abstain from coitus with his wife in the last night of a meat-free week, because it was believed that other- 
wise wolves would eat their pigs (Ivanov 1907: 77). In the Russian North the bridegroom is told to avoid sexual intercourse with his bride on the first marital night: Ты её не тронь, и волк не тронет овеиек 'Do not touch her and the wolf will not touch your sheep' (Balashov \& Marchenko \& Kalmykova 1985: 296). We can assume that the same reasons underlie the requirement that a shepherd in the Russian North is chaste while herding cattle (Uspenski 1982: $95,151)$.

Pecking is another symbol of coitus. During a Christmas and sometimes a wedding ceremony a person dressed as a stork represents a sexual symbol, pecking girls with his beak (compare the stork's role in giving birth - people believe that a stork brings children; on phallic symbolism of stork's beak see Doucet 1971). A goose pecking also has erotic meaning. Girls of western Slavic cultures used geese in fortune-telling about their marriage. They let a goose enter the room and thought that a girl pecked by a goose would be the first to marry (Kolberg 1962b: 95; Pośpiech 1987: 17; Schneeweis 1953: 85). A Bulgarian legend of the creation of Adam and Eve explains the origin of the woman's genitals by a stork pecking Eve between the legs. As the result the stork's beak and legs became red with her blood (Badalanova 1993: 134).

Digging is also a symbol of coitus. Thus in Polish Podlesje the prohibition of sleeping with the wife on Sunday is explained by the belief that otherwise a mole will dig mounds in the field and in the vegetable garden (Witowt 1902: 117). In Zavolzhie there is a Russian custom - the best man, accompanying the newly married couple to bed, tells the bridegroom: Ройся в шерсти 'Dig in hair' (Uspenski 1982: 105). Bulgarian men during the first marital night dancе чукане на пипер - a dance imitating pepper planting in the ground and sexual movements as in sexual intercourse (Ivanova 1984: 128; Vakarelski 1977: 486). A Polish riddle about harrowing a cabbage field (see the above description of the female sexual symbolism of cabbage) is an allegory of coitus: Kiedy mają kolce u brony wesele? - Gdy orza kapuścisko, bo wtedy kwiczą z powodu głębi 'When do the harrow teeth have the wedding? - When ploughing a field where cabbage was, because the teeth gnash from deep digging' (Gonet 1896: 229).

Symbols of coitus and defloration are reflected in the texts of folklore songs. The most popular themes of the kind are breaking guil- 
der rose, ash tree, rose, cabbage, etc. For example, a Byelorussian wedding song, performed during the first marital night:

А ездзіу Якубка з гары $\breve{y}$ мох, Yakubka travelled from the mountain to the moss,

Наламау калінкі колькі мог. Broke as much guilder rose as he could.

За ім молайцы хадзілі,

У Якуба каліны прасілі.

Young guys followed Jakub,

Asked him to give them some guilder rose.

- Я не дам каліны нікому, - I will not give the guilder rose to anyone,

Я гэту каліну сам садзіцу, I was planting it myself, Мне гэту Аўдульку бог судзіц̆, God promised me this Avdulka, Я гэту каліну сам палівау, I was watering the guilder rose myself,

Мне гэту Аўдульку бог даравац

God gave me this Avdulka.

(Viaselle 1988: 201)

Another symbol of sexual intercourse in songs of eastern Slavic cultures is the theme of a hare eating cabbage, where the hare symbolises the male and the cabbage - the female principle. In other songs, where cabbage eating symbolises coitus, instead of a hare and cabbage a pair is acting: a girl and a head of cabbage (i.e. cabbage stump, a male symbol; see Gura 1978: 173-174). The theme of breaking is represented in a southern Russian tradition of "breaking guilder rose," related to defloration of the bride on the first marital night (Grinberg). The same theme we see in the linguistic definitions of defloration: Rus. ломать кесареикого, Bulg. Разваляне (SRNG, ed. 17: 118; Gura 1990: 35).

The theme of trampling (often by horse) grass, flax, garden, yard or grape is popular in Russian folklore. For example,

Сеяли девушки лен.

Повадился Вася шеголек-

Весь леночик притоптал,

Все головки посорвал. /---/

'Выйди, девушка, за меня!'

(Avtamonov 1902: 269-270)
Girls were planting flax.

Vasia-fop used to go to the field

He trampled the flax,

He tore off the heads. /---/

"Marry me, girl!"” 
The theme of trampling is of loving and erotic nature and often is associated with coitus. Thus when Russians wanted to know whether the bride had remained a virgin until marriage, they asked the bridegroom after the first night: Лёд ломал или грлзь топтал? 'Were you breaking ice or trampling dirt?' (Komorovský 1976: 257). Compare also the Russian and Ukrainian words of coitus speaking about birds: Rus. monmamb, Ukr. monmamu 'to have sexual intercourse (about birds)' (Dal 1978-1980: 4: 417; Grinchenko 1958-1959: 4: 274).

The poetic theme of a horse drinking, popular in ballads, lyric, wedding and other songs, also serves as an erotic symbol: a guy asks a girl permission to water his horse or a girl herself offers to give water to the horse. For example, in a Voronezh dancing song a girl throws a bunch of guilder roses to a young officer and asks him:

Возьми мене с собой,

Я тебе буду верной слугой.

/---/ Свожу коня напою, /---/

Постелюшку мягко постелю (Lazutina 1974: 97)

Take me with you,

I will be a faithful servant to you.

/---/ I will water your horse, /---/

I will make a soft bed for you

\section{I will make a soft bed for you}

Giving water to a horse openly represents coitus in a Russian erotic tale about a shy lady, where the horse is the symbol of the penis, and the well - the symbol of the vulva. A lady made her servant promise that he would not say anything indecent; then she suggested that they undress and swim together. They had an allegorical dialogue: "Look, what is it that I have? - pointing at her groin. This is a well, says the servant. - Yes it is! And what do you have hanging there? - It is called a horse. - Does your horse drink? Sure it does. May it drink from your well?" (Afanasev 1992: 58-59). Compare also similar Ukrainian texts: годувать коня 'futuere' коник, лошадка 'penis' (Krauss 1908: 334, 366).

Other actions also symbolically represent coitus: чесать 'scratch', скрести 'scrape', драть 'tear', ковать 'hammer'. Coitus is related to scratching in popular erotic tales and jokes: Rus. чесать, Ukr. чисать, почисать марфутку (марфутка 'vulva') (Afanasev 1992: 83; Krauss 1908: 19, 20, 402). This symbol of scratching / combing can be related to some functions of a comb as a means of a girl's foretelling about her future bridegroom and of love magic: girls put their combs under their pillow for the night or hang them out of the window in 
order to learn who would come to comb their heads; combed heads of boys to charm them; the comb of a girl abandoned by a guy was burned at parties as a way of mockery (see Tolstaia 1995: 541).

Russians in the North call sexual intercourse скребенье (Gerasimov 1910: 79). The euphemism скрёб твою мать (Dal 1912-1914: 3: 869), as well as the word for the last child of the family, поскрёбыш (Dal 1912-1914: 3: 334), are also related to coitus.

The Russian vulgar word dpams 'futuere' is well known. The same action describes coitus for western Ukrainians: Gutsuls put half of a wreath on the head of a bride who lost her virginity before marriage, as a token of shame "she has torn, scratched her wreath" (Komorovský 1976: 61). Bulgarians sing to a dishonest bride who has not kept virginity until the wedding (Шипки ли си брала, дупе ли си драла? 'Have you gathered dog rose? Have you scratched your hole?' (Badalanova 1993: 246).

Coitus is symbolically referred to as strikes of the smith's hammer. This can be seen in a Polish comic song about a smith beating a woman's rear with a hammer:
Od Krakowa jade,
I was travelling from Krakow
Kowal babe stali;
And saw how a smith
Położył jom na pniaku,
Put a woman on a stump
Młotem w tyłek wali
And horseshoed her rear with a hammer

(Rawicz-Witanowski 1893: 75)

Erotic plays - horseshoeing a "lump" bride at a wedding and women and girls during the Maslenitsa (Easter) - are well known for people of western Slavic cultures. In the course of the games men lift women's skirts, touch their naked feet, etc. (Komorovský 1976: 267).

Words used to describe coitus include colour code. Russians know the expression куру пестрить 'futuere' (Zavoiko 1914: 162). The word куриия in the Ukraine and Polesje defines female genitals (Krauss 1908: 37, 122; author's recording from Polesje). Semantically close is another name for coitus, registered in the Russian and Ukrainian languages: Rus. пежить, Ukr. Піжить (Zelenin 1914b: 568; Krauss 1908: 208, 341) - from пегий 'multicoloured, spotted.' It is important to re- 
member that the adjective пегий usually describes the colour of the horse, which often, as we have seen, serves as a male sexual symbol.

Coitus can also be allegorically represented as achieving wealth (gold, money) (see Uspenski 1982: 150-151; 1993: 97). In folklore texts the female genitals are represented as a golden hole. For example, a riddle of a ring put on a finger: Стоит девка на горе, да дивуется дыре: свет моя дыра, дыра золотая! куда тебя дети? на живое мясо вздети 'A girl is standing on a hill and wondering about a hole: oh my hole, my golden hole, where should I put you? I will put you on living flesh' (Afanasev 1994: 467). The same metaphor is used in the ballad about Stavr Godinovich, where coitus is allegorically represented as a fid play (a player throws a fid - a thick nail - trying to target a ring on the ground):

У тебя-де была свайка серебреная,

А у меня кольио позолоченое,

И ты меня поигравал

(Evgeneva \& Putilov 1977: 76)
You had a silver fid

And I had a golden ring

And you played with me

Compare also an allegoric description of coitus in the ancient Russian story "A story about a young man and a girl." The young man makes an indecent offer: Душечка еси ты прекраснал девица! есть у тебя красное золото аравитское, вделал бы я свою жемчюжину в твое чистое серебро 'Oh nice and beloved girl! You do have beautiful Arabian gold! I would insert my pearl into your pure silver' (Loparov 1894: 16). In one of the Russian "forbidden tales" a girl says to a boy about his penis: Да твоим богатством можно денежки доставать! 'You can get money with your wealth!' (Afanasev 1992: 32). Another tale describes coitus as a means of fishing for gold (rings, earrings) from the vulva with the penis (Afanasev 1992: 69-70).

It looks like the belief that sexual intercourse is a way to get wealth underlies the expression Туда даром, обратно с товаром 'take goods', registered at the Russian North as used by Zaonezie fishermen and hunters. Compare the riddle about childbirth registered in the same local tradition: Туда даром, обратно с товаром 'One way free, back with merchandise', where "merchandise" stands for a child as the result of sexual intercourse (Loginov 1996: 451). Coitus was a ceremony within a professional community of fishermen and hunters. 
They specially committed sexual intercourse before long-term hunting, expecting good luck and large game.

On the day before leaving, a fisherman or a hunter told his wife to warm up the sauna before sunset. He went to the sauna with his wife and committed coitus in complete silence. If neighbours or other people passed by, in accordance with the tradition they could not turn away but had to wish good luck, saying "Бог в помощь” or “Помогай вам Бог." No answer was expected. The coitus should have been continued in complete silence until its natural end. Then the fisherman / hunter washed alone in the sauna and after that he did not touch his wife any more. /---/ Old men who were not able to have sexual intercourse carried out a ritual of "diving" between the legs of his old wife, who stood on two seats in the sauna. (Loginov 1996: 445)

After this ceremonial coitus and until the end of the fishing season the fisherman avoided any sexual contact in order not to draw bad luck to the whole team.

Therefore in the language of culture not only different actions and motives have erotic symbolism, establishing their link with coitus, but also coitus itself may have different symbolic meaning and functions.

Thus coitus is a symbol of marital unity. The physical act - the sexual intercourse of the newly married couple - forms a physical connection between wife and husband. That is why coitus and defloration were often considered obligatory on the first marital night. The semantics of unity is reflected in the names of the wedding night ceremonies (Bulg. сводене, свеждане, събиране, Serbian сво Іене, slaganje; Ivanova 1984: 126; Schneeweis 1961: 76), and in the words connected to sexual intercourse (Rus. вступить в связь, иметь близость, сожительствовать, путаться, плестись с кем-либо, склещиться, Pol. spółkować, Bulg. събирам се; see SRNG 1982, ed. 27: 119; Afanasev 1992: 59). In the region of Luga a young man and a girl specially had coitus nine days before Christmas or on Ash Wednesday. It was a security that they would get married within one year (Schulenburg 1882: 127; Veckenstedt 1880: 440). The same meaning at the coast of the White Sea has so-called яровуха - a night passed by guys and girls and the bride and bridegroom together after party in the house 
of the bride not long before the date of the wedding (Bernshtam 1974: 186), and in northeastern Slovakia - erotic games of the bride's female friends with guys, members of the wedding party of the bridegroom, as well as their common night spent in pairs in the house of the bride on the day before the wedding (Horvatová 1974: 255).

Coitus also fastens a ritual relationship: in Luga - of the bridegroom's and bride's father and mother, in Polish Silesia - of the bridegroom's best friend and bride's best friend, who share a bed at the wedding, as well as godparents on the day of baptism (Gasparini 1973: 326-327).

Fertilising symbolism of coitus is represented in rituals and magic stimulating childbirth, livestock yield, vegetation, fertility and a better harvest. For example, Serbs stimulated coitus under a fruit tree, on the field before sowing, in the course of sowing millet. The place in the field designated for ritual coitus had a special name јебалиште (Krauss 1904: 7, 159). To speed up corn growing the farmer committed sexual intercourse with a woman and said Какогод брзе јеб изишо, тако брзо и кукуруз нико 'Let the corn grow as fast as the coitus was committed' (Krauss 1904: 159). In western Serbia a man who wanted to have many horses tried to have sex with a Gipsy woman (Krauss 1904: 7).

The theme of coitus is also present in the spring, Ianka Kupala and wedding ceremonies. There is a lot of evidence of promiscuity on Mardi Gras, the days of St. John and St. Peter (sexual intercourse during plays on these days) (see Bernshtam 1988: 228, 236-237). Coitus done in the field during spring holidays has a magic function - to improve the fertility of the field. In western Bulgaria, early in the morning of St. John's Day, a naked woman walked by her field and took several ears. Then she had sexual intercourse with her husband or lover who was hiding nearby. In the Ukraine in Polesie near Zhitomir, on St. George's Day men with women and boys with girls rolled in pairs on the ground, imitating coitus to stimulate the harvest of crops. In Macedonia husbands and wives imitated coitus on Mardi Gras with the same goal. In western Bulgaria on St. John's Day women and girls rolled on the gathered grass with naked bottoms in order for the grass to obtain healing properties. On St. Jeremiah's Day (May 1) people rolled in pairs on the grass, imitating coitus. $^{7}$ 
In eastern Moravia people performed a žabská dance, imitating coitus on Mardi Gras and at the end of a wedding, where it was usually danced by husbands and wives. The meaning, attributed to this dance, was to ensure childbirth for the newly married couple (Komorovský 1976: 224; Gratsianskaia 1975: 152). The underwear worn during coitus also has this symbol. For example in Vladimirskaya gubernia a woman beat her cow with a shirt in which she has slept with the husband to stimulate the cow's sexual activity (Zavoiko 1914: 121).

Coitus is one of the most important objects of allegory among different types of human activity. In traditional popular culture it corresponds to a wide paradigm of behavioural symbols. The paradigm is built on the basis of motivating indicators reflecting the external properties of action: joining together (coitus as a connection, weaving, hobbling, pressing with pincers), mobility (roll, somersault, dance), insertion (bite, sting, peck, prod, dig, sow, harrow), rhythm and repetitive action (hammer, carve, trample), oscillation (wave), friction at close contact (scratch, scrape), posture when doing this action (sit astride), defloration as the result of coitus (break, tear, perforate), etc.

The basis of the symbolic meanings attributed to sexual intercourse as a means of magic of traditional popular culture is the similarity of physical sexual contact to social contacts (marriage, ritual relations), as well as metaphorical extrapolation of its natural result (conception of the fetus) to the results of human activity (harvest, cattle, big game hunting or fishing). We have consciously put aside all other meanings and functions of coitus, first of all the vast amount of prohibitions, imposed on coitus due to requirements of ritual purity or caused by the belief that it can be dangerous.

\section{Comments}

${ }^{1}$ Archives of the Etnographical Institute and Museum (Sofia), No. 776II, p. 7; No. 878-II, p. 53; No. 879-II, p. 7.

${ }^{2}$ Archives of the Folklore Chair of the Moscow State University, recorded by E. E. Eremiian, O. Yu. Fominykh. 
3 Sonnik polskoi [Polish Interpreter of Dreams]. Russian National Library (St. Petersburg), Department of Manuscripts, fund 777 (P. N. Tikhanov's collection), fund description No. 3, No. 308, list 328.

${ }^{4}$ Sonnik polskoi [Polish Interpreter of Dreams]. Russian National Library (St. Petersburg), Department of Manuscripts, fund 777 (P. N. Tikhanov's Collection), fund description No. 3, No. 272, list 56.

${ }^{5}$ Овещахь розніхъ яже восн кому являють са [Planet and Dream Interpreter in the Ukrainian Dialect]. Russian National Library (St. Petersburg), Department of Manuscripts, Q. III, No. 208.

${ }^{6}$ Archives of the Etnographical Institute and Museum (Sofia), No. 776II, p. 16.

7 The previous examples were taken from the article by Agapkina 1996: $245-246$.

\section{References}

Afanasev, A. N. (Ed.) 1992. Russkie zavetnye skazki [Forbidden Russian Tales]. Moscow: Moskovski knizhnyi dvor.

Afanasev, Aleksandr N. 1865 [reprint 1994]. Poeticheskie vozzreniia slavian na prirodu. Opyt sravnitelnogo izutcheniia slavianskikh predani $i$ verovani $v$ sviazi s mificheskimi skazaniiami drugikh rodstvennykh narodov [Slavic Poems about Nature. On Comparative Study of Slavic Tales and Beliefs and Myths of Other Related Nations], 1. Moscow.

Agapkina, Tatiana A. (ed.) 1996. Kontsept dvizheniia v iazyke i kulture [Concept of Movement in Language and Culture]. Biblioteka Instituta slavianovedeniia i balkanistiki, 5. Moscow: Indrik.

Avtamonov, Iakov 1902. Simvolika rasteni v velikorussikh pesniaks [Plants as Symbols in Russian Songs]. Zhurnal ministerstva narodnogo prsveshcheniia [Magazine of the Ministry of Popular Education], 334 (12). St. Petersburg, pp. 234-288.

Badalanova, Florentina K. (ed.) 1993. Folkloren erotikon [Folklore Eroticon], 1. Sofiia: ROD.

Balashov, Dmitri M. \& Marchenko, Iuri. I. \& Kalmykova, Nadezhda I. 1985. Russkaia svadba: Sladebnyi obriad na Berkhnei $i$ Srednei Kokshenge i na Uftiuge (Tarnogski raion Bologodskoi oblasti) [Russian Wedding. Wedding Ceremony at Verhkniaia and Sredniaia Kokshenga and at Uftiug (Tarnogki region of Vologodskaia Oblast)]. Moscow: Sovremennik.

Bernshtam, Tatiana A. 1974. Svadebnaia obriadnost na Pomorskom i Onezhskom beregakh Belogo moria [Wedding Ceremony at Pomorski and Onezhski Seashore of the White Sea]. Putilov, Boris N. (ed.). Folklor $i$ 
etnografiia: Obriady $i$ obriadovyi folklor [Folklore and Ethnography. Ceremonies and Ceremonial Folklore]. Leningrad: Nauka, Leningr. otdnie.

Bernshtam, Tatiana A. 1988. Molodezh v obriadovoi zhizni russkoi obshchiny 19 - nachala 20 v. Polovozrasstnoi aspekt trditsionnoi kultury [Youth in the Ritual Life of the Russian Community in the 19th and Early 20th Century. Gender and Age Aspect of Traditional Culture]. Leningrad: Nauka, Leningr. otd-nie.

Dal, Vladimir I. 1912-1914 [1978-1980]. Toklovyi slovar zhivogo velikorusskogo iazyka [Explanatory Dictionary of the Russian Living Language], 1-4. St. Petersburg \& Moscow. Moscow 1978-1980: Russkii iazyk (photocopy).

Doucet, F. W. 1971. Taschenlexikon der Sexualsymbole. (Mensch und Sexualität, 21.) München: Heyne.

Dzitsiachy 1972 = Kabashnikav, Kanstantin P. \& Bartashevich, Halyna A. \& Ialatov, Nikolai K. (comps.). Dzitsiachy falklor [Childeren's Folklore]. (Belaruskaia narodnaia tvorchasts.) Minsk.

Evgeneva, Anastasia P. \& Putilov, Boris N. (eds.) 1977. Drevnie rossiskie stikhotvoreniia, sobrannye Kirsheiu Danilovym [Ancient Russian Poems Collected by Kirsha Danilov]. 2nd improved edition. (Literaturnye pamiatniki) [Literary monuments]. Moscow: Nauka.

Gasparini, Evel 1973. Il matriarcato Slavo: Antropologia culturale dei protoslavi [The Matriarchy of Slavs]. Firenze: Sansoni.

Gerasimov, M. K. 1910. Slovar uezdnogo cherepovetskogo govora [Dictionary of Cherepovets' Local Dialect. St. Petersburg]. (Sbornik Otdeleniia russkogo iazyka i slovesnosti Imperatorskoi Akademii Nauk, 37 (3)) [Collection of the Department for Russian Language and Philology of the Emperor's Academy of Science, 37 (3)]. St. Petersburg: Imperatorskaia Akad. Nauk.

Gonet, S. 1896. Dowcipne pytania i zagadki [Humorous Questions and Riddles]. Lud: Organ Polskiego Towarzystwa Ludoznawczego $i$ Komitetu Nauk Etnologicznych, 2 (3). Lwów: Tow.

Gonet, S. 1909. Śpiewki z okolicy Andrychowa [Songs of Andrychow region]. Lud: Organ Polskiego Towarzystwa Ludoznawczego $i$ Komitetu Nauk Etnologicznych, 15 (1-2). Lwów: Tow.

Gratsianskaia, Natalia N. 1975. Etnograficheskie gruppy Moravii. K istorii etnicheskogo razvitiia [Ethnographic Groups of Moravia. On the History of Ethnic Development]. Moscow: Nauka.

Grinberg, I. M. (= Tsirelman). Iuzhnorusskaia svadebnaia terminologiia [Southern Russian Wedding Terminology]. Diploma thesis. Archive of the Chair of Russian Language at the Moscow State University.

Grinchenko, Boris D. 1907-1909 [1958-1959]. Slovar ukrainskogo iazyka, sobrannyi redaktsiei zhurnala "Kievskaia starina". (Slovar ukrainskoi movi. Zibrala redaktsia zhurnala "Kievskaia starina") [Dictionary of Ukrainian language, collected by the editorial staff of 
Kievskaia starina magazine], 1-4. Kiev. Kiev 1958-1959: Vyd-vo Akademii nauk Ukr. RSR (photocopy).

Gura, Aleksandr V. 1978. Simvolika zaitsa v slavianskom obriadom i pesennom folklore [Hare as a Symbol in Slavic Folklore Songs and Ceremonies]. Sheptunov, Igor M. et al. (eds.). Slavianski $i$ balkanski folklor: Genezis. Arkhaika. Traditsii [Slavic and Balkan Folklore. Genesis. History. Traditions]. Moscow: Nauka.

Gura, Aleksandr V. 1990. Pravata brachna noshch v slavianskiia svatben obred [Rights of the Wedding Night in Slavic Wedding Custom]. Benovska-Sbkova, Milena (ed.). Zemiat v Blgarskiia folklor, 1. Sofiia: Akad. izdat. Marin Drinov.

Gura, Aleksandr V. 1997. Simvolika zhivotnykh v slavianskoi narodnoi traditsii [Animal Symbols in Popular Slavic Tradition]. Traditsionnaia dukhovnaia kultura slavian: Sovremennye issledovaniia [Traditional Spiritual Slavic Culture: Modern Studies]. Moscow: Indrik.

Haase, Felix 1939. Volksglaube und Brauchtum der Ostslaven. Wort und Brauch: Volkskundliche Arbeiten namens der Schlesischen Gesellschaft für Volkskunde, 26. Breslau: Märtin.

Horvatová, Emilia 1974. Duhovná kultura [Mental Culture]. Horehronie. Bratislava.

Ivanov, P. 1907. Zhizn i poveria krestian Kupianskogo uezda Kharkovskogo gubernii [Life and Beliefs of Peasants in Kupianslyi uezd of Kharkovskaya guberniya]. Sbornik Kharkovskogo Istoriko-filologicheskogo obshchestva, sostoiashchego pri Imperatorskom Kharkovskom universitete, 17 [Collection of Kharkov Society for History and Philology at the Kharkov Emperor's University, 17]. Kharkov.

Ivanova, Radost T. 1984. Blgarska folklorna svadba [Bolgarian Traditional Wedding]. Sofiia: Izdat. na Blgarskata Akad. na Naukite.

Jakobson, Roman 1934-1936. Slezsko-polská cantilena inhonesta ze začátku XV. Století [Silesian-Polish cantilena inhonesta at the beginning of the 15th century]. Národopisný věstník českoslovanský [Checkoslovakkian Ethnological Bulletin], 27-28. Praha: Pražské Akciové Tiskárny.

Kolberg, O. 1962a. Dzieła wszystkie [Collected Works], 2: Sandomierskie. Wrocław \& Poznań: Polskie Tow \& Ludoznawcze.

Kolberg, O. 1962b. Dzieła wszystkie [Collected Works], 3: Kujawy, I. Wrocław \& Poznań: Polskie Tow \& Ludoznawcze.

Kolberg, O. 1962c. Dzieła wszystkie [Collected Works], 29: Pokucie, I. Wrocław \& Poznań: Polskie Tow \& Ludoznawcze.

Komarov, M. (ed.) 1890. Nova zbirka narodnikh maloruskikh prykazok, prysliviv, pomovok $i$ zamovlian [New Collection of Ukrainian Folk Sayings, Bywords, Adagaes and Incantations]. Odessa.

Komorovský, J. 1976. Tradičná suadba u Slovanov [Taditional Wedding among Slovenes]. Bratislava: Univ. Komenského. 
Krauss, Friedrich Salomo von (ed.) 1904. Anthropophyteia. Jahrbücher für folkloristische Erhebungen und Forschungen zur Entwicklunggeschichte der geschlechtlichen Moral, 1. Leipzig: Dt. Verl.-Aktien-Ges.

Krauss, Friedrich Salomo von (ed.) 1909. Das Geschlechtleben des ukrainischen Bauernvolkes, 1: Folkloristische Erhebungen aus der Russischen Ukraina. Tarasevśkyj, Pavlo (Aufzeichnungen) \& Hnatjuk, Vołodimir (Einleitung und Parallelennachweise). Beiwerke zum Studium der Anthropophyteia, 3. Leipzig.

Kryptadia 1899 = Die Zeugung in Sitte, Brauch und Glauben der Südslaven. Kryptadia: Recueil de documents pour servir à l'étude des traditions populaires, 6. Paris.

Lazutin, Sergei G. (ed.) 1974. Narodnye pesni Voronezhskoi oblasti [Folk Songs of the Voronezhskaia Oblast]. Voronezh: Izd. Voronezh. Univ.

Loginov, Konstantin K. 1996. Materialy po seksualnomu povedeniiu russkikh Zaonezhiia [Materials on Sexual Behaviour of Russians in Zaonezhie]. Toporkov, Andrei L. (ed.). Seks i erotika v russkoi traditsionnoi kulture [Sex and Erotica in the Russian Traditional Culture]. Russkaia potaennaia literatura: Russki eroticheski folklor. Moscow: Ladomir.

Loparev, Khirsanf 1894. Skazanie o molodtse $i$ devitse: Vnov naidennaia povest narodnoi literatury: Soobshchenie Khirsanfa Lopareva [Story about a Young Man and Girl: Recently Found Folklore Novel: Report by Khrisanf Loparev]. Pamiatniki drevnei pismennosti, 99. St. Petersburg.

Plotnikova, Anna A. \& Usacheva, Valeria V. 1995. Gorokh [Pea]. Tolstoi, Nikita I. et al. (eds.) \& Agapkina, Tatjana A. et al. (comps.). Slavianskie drevnosti. Etnolinguistichestki slovar v piati tomakh [Slavic Relics. EthnoLinguistic Dictionary], 1. Moscow: Mezhdunarodnye otnosheniia.

Pośpiech. Jerzy 1987. Zwyczaje i obrzędy doroczne na Śląsku [Silesian Calendar Traditions and Rites]. Opole.

Rawicz-Witanowski, Michał 1893. Lud wsi Stradomia pod Częstochową [Peasants of Stradomia near Czestochowa]. Zbiór wiadomości do antropologii krajowej [Collection of Records of National Anthropology], 17. Kraków.

Romanov, Evdokim 1889. Opyt belorusskogo narodnogo snotolkovatelia [Popular Byelorussian Interpreter of Dreams]. Etnograficheskoe obozrenie [Ethnographical Review], 3. Moscow.

Schneeweis, Edmund 1953. Feste und Volksbräuche der Sorben vergleichend dargestellt. Deutsche Akademie der Wissenschaften zu Berlin. Veröffentlichungen des Instituts für Slawistik, 3. Berlin: AkademieVerlag.

Schneeweis, Edmund 1961. Serbokroatische Volkskunde, 1: Volksglaube und Volksbrauch. Grundriß der slavischen Philologie und Kulturgeschichte, 14. Berlin: de Gruyter. 
Schulenburg, Wilbald von 1882. Wendisches Volksthum in Sage, Brauch und Sitte. Berlin: Nicolai.

Skierkowski, Władyslaw 1929. Puszcza Kurpiowska $w$ pieśni [The Kurpie Forest in Song], 2 (1). Płock.

Skierkowski, Władyslaw 1933. Puszcza Kurpiowska $w$ pieśni [The Kurpie Forest in Song], 2 (2). Płock.

SRNG = Filin, Fedot P. (comp.). Slovar russkikh narodnykh govorov [Dictionary of Russian Dialects]. Moscow: Nauka.

Stern, Bernhard 1908. Geschichte der offentlichen Sittlichkeit in Russland, Kultur, Aberglaube, Sitten und Gebrauche, 2: Russische grausamkeit, das weib und die ehe, geschlechtliche moral, prostitution, gleichgeschlechtliche liebe, lustseuche, folkloristische dokumente. Berlin: H. Barsdorf.

Sychta, Bernard 1976-1976. Słownik gwar kaszubskich na tle kultury ludowej [Dictionary of the Kashubian Language Based on Folk Culture], 1-7. Wrocław \& Warszawa \& Kraków \& Gdańsk.

Tolstaia, Svetlana M. 1995. Greben [Comb]. Tolstoi, Nikita I. et al. (eds.) \& Agapkina, Tatjana A. et al. (comps.). Slavianskie drevnosti. Etnolingvisticheski slovar [Slavic Antiques. Ethno-Linguistic Dictionary], 1. Moscow: Mezhdunarodnye otnosheniia.

Uspenski, Boris A. 1993. "Zavetnye skazki" A. N. Afanaseva [The Fobidden Tales of A. N. Afanasev]. Badalanova, Florentina (ed.). Folkloren erotikon, 1. Sofiia: Impresarsko-izdatelska kvshta ROD.

Uspenski, Boris A. 1982. Filologicheskie razyskaniia $v$ oblasti slavianskikh drevnostei: Relikty iazychestva $v$ vostochnoslavianskom kulte Nikolaia Mirlikiiskogo [Philological Research of Slavic Antiques: Pagan Relics in Eastern the Slavic Cult of St. Nicholas of Myra]. Moscow: Izd-vo Moskovskogo universiteta.

Vakarelski, Khristo 1977. Etnografiia na Blgariia [Bolgarian Etnography]. Sofiia: Nauka i izkustvo.

Veckenstedt, Edmund 1880. Wendische Sagen, Märchen und Abergläubische Gebräuche. Graz: Leuschner \& Lubensky.

Viaselle 1988 = Malash, Leanila A. (comp.) \& Hrynblat, Mikhail J. \& Fiadosik, Anatol S. (eds.). Viaselle: Pesni [Wedding: Songs], 6. Belaruskaia narodnaia tvorchasts. Minsk: Navuka i tekhnika.

Witowt [= Vytautas, Grand Duke of Lithuania] 1902. Kilka przesądów ze wsi Turowa (powiat Radzyński) [Some Beliefs from Turow Region (Radzynski District)]. Wisła: Miesięcznik geograficzno-etnograficzny, 16. Warszawa.

Zavarin, N. 1870. O sueveriiakh i predrassudkakh, sushchestvuiushchikh v Vologodskoi eparkhii [On Superstitions and Prejudices in the Vologda Eparchy]. Vologodskie eparkhialnye vedomosti [Newspaper of the Vologda Eparchy], 3. Vologda. 
Zavoiko, G. K. 1914. Verovaniia, obriady i obychai velikorussov Vladimirskoi gubernii [Beliefs, Ceremonies and Traditions of Russians in Vladimirskaia gubernia]. Etnograficheskoe obozrenie [Ethnographic Review], 103-104 (3-4). Moscow.

Zelenin, Dmitri K. 1914a. Opisanie rukopisei Uchenogo arkhiva Imperatorskogo Russkogo geografischeskogo obshchestva [Description of Manuscripts of the Scientific Archive of the Emperor's Russian Geographical Society], 1. Petrograd: Imperatorskoe Russkoe geograficheskoe obshchestvo.

Zelenin, Dmitri K. 1914b. Velikorusskie skazki Permskoi gubernii [Russian Tales of Permskaia guberniia]. Petrograd: Tip. A. V. Orlova. 